Article

\title{
Sterols from the Green Alga Ulva australis
}

\author{
Guo-Liang Li, Wei-Jie Guo, Guang-Bao Wang, Rong-Rong Wang, Yu-Xue Hou, Kun Liu, Yang Liu \\ and Wei Wang *
}

Department of Natural Medicine and Pharmacognosy, School of Pharmacy, Qingdao University, Qingdao 266071, China; qdguoliangli@163.com (G.-L.L.); wfenterance@163.com (W.-J.G.); qddxgbwang@163.com (G.-B.W.); rrwang2012@163.com (R.-R.W.); hyx19931008@163.com (Y.-X.H.); kunliu62@126.com (K.L.); buckuper@163.com (Y.L.)

* Correspondence: qddxwangwei@qdu.edu.cn or w.w.wangwei@263.net; Tel.: +86-532-8699-1172

Received: 12 August 2017; Accepted: 27 September 2017; Published: 28 September 2017

\begin{abstract}
Three new sterols, (24R)-5,28-stigmastadiene-3 $\beta$,24-diol-7-one (1), (24S)-5,28-stigmastadiene$3 \beta, 24$-diol-7-one (2), and $24 R$ and $24 S$-vinylcholesta-3 $\beta, 5 \alpha, 6 \beta, 24$-tetraol (3), together with three known sterols (4-6) were isolated from the green alga Ulva australis. The structures of the new compounds (1-3) were elucidated through 1D and 2D nuclear magnetic resonance spectroscopy as well as mass spectrometry. Compounds 4-6 were identified as isofucoterol (4), $24 R, 28 S$ and 24S,28R-epoxy-24-ethylcholesterol (5), and (24S)-stigmastadiene-3 3,24 -diol (6) on the basis of spectroscopic data analyses and comparison with those reported in the literature. Compounds 4-6 were isolated from $U$. australis for the first time. These compounds, together with the previously isolated secondary metabolites of this alga, were investigated for their inhibitory effects on human recombinant aldose reductase in vitro. Of the compounds, $24 R, 28 \mathrm{~S}$ and 24S,28R-epoxy-24-ethylcholesterol (5), 1-O-palmitoyl-3-O-(6'-sulfo- $\alpha$-D-quinovopyranosyl) glycerol, (2S)-1-O-palmitoyl-3-O-[ $\alpha$-D-galactopyranosyl $(1 \rightarrow 2) \beta$-D-galactopyranosyl] glycerol, 4-hydroxybenzoic acid, 4-hydroxyphenylacetic acid, and 8-hydroxy-(6E)-octenoic acid weakly inhibited the enzyme, while the three new sterols, $1-3$, were almost inactive.
\end{abstract}

Keywords: Chlorophyta; Ulva australis; 5,28-stigmastadiene-3 $\beta, 24-$ diol-7-one epimers; 24-vinylcholesta$3 \beta, 5 \alpha, 6 \beta, 24$-tetraol

\section{Introduction}

Marine organisms have recently received much attention in the search for structurally interesting compounds with a wide range of pharmacological activities to develop new medicines or health foods [1-5]. Approximately 8000 species of marine algae have been identified and grouped into different classes, including brown algae (Phaeophyta), red algae (Rhodophyta), and green algae (Chlorophyta). Ulva australis Areschoug is a green alga belonging to the family Ulvaceae and is widely distributed along the coasts of the Yellow Sea and the Bo Sea of China. As an edible seaweed, it contains high nutritional value minerals, vitamins, and noncaloric dietary fibers [6]. Ulva australis is consumed by local inhabitants of Asia [7] and has been authorized for human utilization by French authorities [8]. In addition to edibility, the decoction of this alga has been accepted as a natural traditional medicine for hyperlipidemia, sunstroke, and urinary diseases [9]. The chemical and pharmacological studies of $U$. australis available in the literature are mostly concerned with the algal polysaccharides. These sulfated polysaccharides have been described to possess diverse biological activities, such as antihyperlipidemic [10], antioxidant [11], antiviral [12], immunomodulatory [13], and anti-radiation activities [14]. However, small-molecule chemical components of $U$. australis and structure identification have only received limited attention [15-17]. It has been recently reported that 3-hydroxy-4,7-megastigmadien-9-one, isolated from this alga, attenuates lipopolysaccharide-induced 
and TLR9-mediated inflammatory responses by downregulating mitogen-activated protein kinase and NF- $\mathrm{kB}$ pathways $[7,18]$. In our search for aldose reductase inhibitors from marine algae, we found that bromophenols isolated from the red alga Symphyocladia latiuscula exhibited significant human recombinant aldose reductase inhibitory activity [19]. The extract from $U$. australis exhibited weak human recombinant aldose reductase inhibitory activity, which is in agreement with the previous report [20]. Our continued interest in discovering new secondary metabolites from marine algae led us to isolate three new sterols, (24R)-5,28-stigmastadiene-3 $\beta, 24$-diol-7-one (1), (24S)-5,28-stigmastadiene-3 $\beta, 24$-diol-7-one (2), and $24 R$ and $24 S$-vinylcholesta-3 $\beta, 5 \alpha, 6 \beta$,24-tetraol (3), together with three known sterols, isofucoterol (4), 24R,28S and 24S,28R-epoxy-24-ethylcholesterol (5), and (24S)-5,28-stigmastadiene-3 $\beta, 24$-diol (6), from the green alga $U$. australis (Figure 1). The structures of these compounds were identified by NMR spectroscopy, mass spectrometry, and compared with those reported in the literature. The configurations of compounds $\mathbf{1}$ and $\mathbf{2}$ were determined on the basis of the chemical shift differences between $\mathrm{H}-27$ and H-26 and between $\mathrm{H}-27$ and H-21. Herein, we also report on the evaluation of the human recombinant aldose reductase inhibitory activities of the compounds isolated by us from this alga.

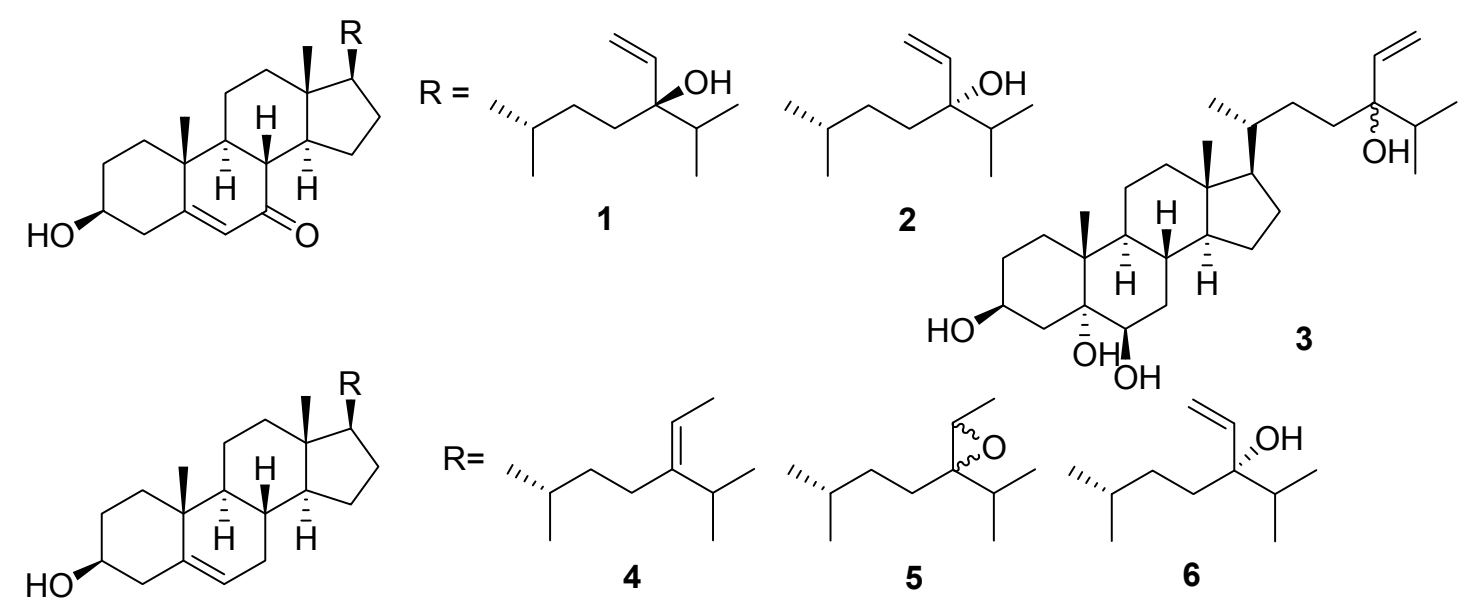

Figure 1. Structures of compounds 1-6.

\section{Results and Discussion}

Compound 1 was isolated as a white amorphous solid. The molecular formula was determined to be $\mathrm{C}_{29} \mathrm{H}_{46} \mathrm{O}_{3}$ by HR-EI-MS at $m / z 442.3445$ (calcd. for $\mathrm{C}_{29} \mathrm{H}_{46} \mathrm{O}_{3} 442.3447$ ). The sterol nature of this compound was deduced from a combination of ${ }^{13} \mathrm{C}$ NMR (Table 1) and distortionless enhancement by polarization transfer spectra. The ${ }^{13} \mathrm{C}$ NMR spectrum of compound 1 showed 29 resonances, which were assigned to five methyl groups $\left(\delta_{\mathrm{C}} 11.9\right.$ (C-18), 16.4 (C-26), 17.3 (C-19), 17.5 (C-27), and 18.9 $(C-21))$, nine sp ${ }^{3}$ methylene carbons ( $\delta_{C} 21.2(C-11), 26.2$ (C-15), 29.0 (C-22), $29.6(C-16), 31.1(C-2)$, 34.8 (C-23), $36.3(\mathrm{C}-1), 38.6(\mathrm{C}-12)$, and $41.7(\mathrm{C}-4))$, one sp ${ }^{2}$ methylene carbon $\left(\delta_{\mathrm{C}} 112.7(\mathrm{C}-29)\right)$, six sp ${ }^{3}$ methine carbons $\left(\delta_{C} 35.8\right.$ (C-25), $36.0(\mathrm{C}-20), 45.3(\mathrm{C}-8), 49.8(\mathrm{C}-14), 49.8(\mathrm{C}-9)$, and $\left.54.4(\mathrm{C}-17)\right)$, one oxygenated $\mathrm{sp}^{3}$ methine carbons $\left(\delta_{\mathrm{C}} 70.4(\mathrm{C}-3)\right)$, two sp ${ }^{2}$ methine carbons $\left(\delta_{\mathrm{C}} 125.8(\mathrm{C}-6)\right.$ and 142.1 (C-28)), two $\mathrm{sp}^{3}$ quaternary carbons $\left(\delta_{C} 38.2(\mathrm{C}-10)\right.$ and $\left.43.0(\mathrm{C}-13)\right)$, one oxygenated sp ${ }^{3}$ quaternary carbon $\left(\delta_{C} 77.5(\mathrm{C}-24)\right)$, one sp ${ }^{2}$ quaternary carbon $\left(\delta_{C} 164.6(\mathrm{~s}, \mathrm{C}-5)\right)$, and one ketone carbonyl carbon $\left(\delta_{C} 201.6(C-7)\right)$. The ${ }^{1} \mathrm{H}$ NMR spectrum of compound 1 had resonances corresponding to two tertiary methyl groups $\left(\delta_{\mathrm{H}} 0.68(\mathrm{~s}, \mathrm{H}-18)\right.$ and $\left.1.20(\mathrm{~s}, \mathrm{H}-19)\right)$, three secondary methyl groups $\left(\delta_{\mathrm{H}} 0.87(\mathrm{~d}\right.$, $J=7.2 \mathrm{~Hz}, \mathrm{H}-26), 0.89(\mathrm{~d}, J=8.0 \mathrm{~Hz}, \mathrm{H}-27)$, and $0.93(3 \mathrm{H}, \mathrm{d}, J=6.4 \mathrm{~Hz}, \mathrm{H}-21))$, an oxymethine proton $\left(\delta_{\mathrm{H}} 3.67(\mathrm{~m}, \mathrm{H}-3)\right)$, and an olefinic proton $\left(\delta_{\mathrm{H}} 5.69(\mathrm{~d}, J=1.6 \mathrm{~Hz}, \mathrm{H}-6)\right)$. The ${ }^{1} \mathrm{H}$ NMR spectrum exhibited an ABX system at $\delta_{\mathrm{H}} 5.14(1 \mathrm{H}, \mathrm{dd}, J=10.8,1.6 \mathrm{~Hz}, \mathrm{H}-29), 5.20(1 \mathrm{H}, \mathrm{dd}, J=17.6,1.6 \mathrm{~Hz}$, $\mathrm{H}-29)$, and $5.81(1 \mathrm{H}, \mathrm{dd}, J=17.6,10.8, \mathrm{H}-28)$, due to the presence of a vinyl group attached to a tertiary carbon. These data, along with mass fragments at $m / z 424\left[\mathrm{M}-\mathrm{H}_{2} \mathrm{O}\right]^{+}, 399\left[\mathrm{M}-\mathrm{C}_{3} \mathrm{H}_{7}\right]^{+}$, 
$381\left[\mathrm{M}-\mathrm{C}_{3} \mathrm{H}_{7}-\mathrm{H}_{2} \mathrm{O}\right]^{+}, 329\left[\mathrm{M}-\mathrm{C}_{7} \mathrm{H}_{13} \mathrm{O}\right]^{+}$, and $285\left[\mathrm{M}-\mathrm{C}_{10} \mathrm{H}_{19} \mathrm{O}-2 \mathrm{H}\right]^{+}$(Figure 2) suggested that compound 1 possessed a 24-hydroxy-24-vinyl side chain [21,22]. The above data thus demonstrated that compound 1 was a $\Delta^{5}$-3 $\beta$-hydroxyl 7-oxysterol derivative, similar to the ring system of decortinone (Table 1), a known sterol previously obtained from the green alga Codium decorticatum [23], and the side chain of 5,28-stigmastadiene-3 $\beta, 24$-diol (Table 1), a known sterol previously isolated from the brown alga Sargassum fusiforme [24]. The stereochemistry of compound $\mathbf{1}$ at C-24 was established to be $\mathrm{R}$, since the signals attributed to $\mathrm{H}-27$ at $\delta 0.890(3 \mathrm{H}, \mathrm{d}, J=8.0 \mathrm{~Hz})$ were close to those of H-26 at $\delta 0.871$ $(3 \mathrm{H}, \mathrm{d}, J=7.2 \mathrm{~Hz})$ in the ${ }^{1} \mathrm{H}$ NMR spectrum of compound 1 . The chemical shift difference between H-27 and H-26 of compound 1 was 0.019 ppm, whereas the chemical shift difference between H-27 and $\mathrm{H}-21$ of compound 1 was $0.041 \mathrm{ppm}$, which was in accordance with those of 24R-saringosterol. The chemical shift difference between H-27 and H-26 of 24R-saringosterol was 0.020 or 0.020 ppm, whereas the chemical shift difference between H-27 and H-21 24R-saringosterol was 0.032 or 0.033 ppm in the previous reports [21,22]. Thus, compound 1 was elucidated with the structure as shown in Figure 1, and named (24R)-5,28-stigmastadiene-3 $\beta, 24$-diol-7-one.

Table 1. ${ }^{13} \mathrm{C}-\mathrm{NMR}$ spectral data of compound 1-3 (100 MHz, $\mathrm{CDCl}_{3}, \delta$ in ppm).

\begin{tabular}{|c|c|c|c|c|c|c|c|}
\hline Position & 1 & 2 & 3 & $a^{1}$ & $b^{2}$ & $c^{3}$ & $d^{4}$ \\
\hline 1 & 36.3 & 36.3 & 30.8 & 36.3 & 37.3 & 37.3 & 30.2 \\
\hline 2 & 31.1 & 31.2 & 32.3 & 31.1 & 32.0 & 32.0 & 33.3 \\
\hline 3 & 70.4 & 70.5 & 67.5 & 70.4 & 71.8 & 71.8 & 66.8 \\
\hline 4 & 41.7 & 41.8 & 40.7 & 41.7 & 42.4 & 42.4 & 39.7 \\
\hline 5 & 164.6 & 164.8 & 75.9 & 164.9 & 140.7 & 140.7 & 75.0 \\
\hline 6 & 125.8 & 126.0 & 75.9 & 126.1 & 121.6 & 121.6 & 75.4 \\
\hline 7 & 201.6 & 201.9 & 34.5 & 202.5 & 31.7 & 31.7 & 35.4 \\
\hline 8 & 45.3 & 45.4 & 30.1 & 45.3 & 32.0 & 32.0 & 30.0 \\
\hline 9 & 49.8 & 49.9 & 45.8 & 49.9 & 50.2 & 50.2 & 45.0 \\
\hline 10 & 38.2 & 38.2 & 38.2 & 38.6 & 36.6 & 36.6 & 37.7 \\
\hline 11 & 21.2 & 21.2 & 21.2 & 21.1 & 21.2 & 21.1 & 20.8 \\
\hline 12 & 38.6 & 38.6 & 39.8 & 38.6 & 39.8 & 39.8 & 39.1 \\
\hline 13 & 43.0 & 43.1 & 42.7 & 43.0 & 42.4 & 42.3 & 42.3 \\
\hline 14 & 49.8 & 49.9 & 55.8 & 49.8 & 56.8 & 56.8 & 55.9 \\
\hline 15 & 26.2 & 26.2 & 24.0 & 26.2 & 24.3 & 24.3 & 22.2 \\
\hline 16 & 29.6 & 29.7 & $28.14 / 28.09$ & 29.3 & 28.2 & 28.3 & 27.6 \\
\hline 17 & 54.4 & 54.5 & 55.8 & 54.6 & 55.9 & 55.9 & 55.6 \\
\hline 18 & 11.9 & 12.0 & 12.1 & 11.6 & 11.9 & 11.9 & 11.6 \\
\hline 19 & 17.3 & 17.3 & 16.8 & 17.2 & 19.5 & 19.4 & 16.1 \\
\hline 20 & 36.0 & 36.0 & 36.0 & 35.4 & 36.0 & 36.0 & 35.8 \\
\hline 21 & 18.9 & 18.9 & 18.7 & 18.7 & 18.9 & 18.8 & 18.2 \\
\hline 22 & 29.0 & 29.1 & 29.0 & 33.3 & 29.1 & 29.2 & 33.6 \\
\hline 23 & 34.8 & 34.8 & $34.8 / 34.6$ & 29.6 & 34.8 & 34.6 & 23.7 \\
\hline 24 & 77.5 & 77.6 & 77.5 & 49.4 & 77.7 & 77.7 & 45.0 \\
\hline 25 & 35.8 & 35.8 & 35.9 & 17.8 & 36.1 & 36.2 & 27.8 \\
\hline 26 & 16.4 & 16.4 & 16.4 & 147.5 & 16.5 & 16.5 & 18.3 \\
\hline 27 & 17.5 & 17.5 & 17.5 & 111.3 & 17.6 & 17.6 & 18.3 \\
\hline 28 & 142.1 & 142.3 & $142.2 / 142.1$ & 26.4 & 142.4 & 142.5 & 22.0 \\
\hline 29 & 112.7 & 112.8 & $112.7 / 112.6$ & 11.9 & 112.9 & 112.8 & 11.8 \\
\hline
\end{tabular}

${ }^{1} \mathrm{a}$, Decortinone, data from [23]; ${ }^{2} \mathrm{~b},(24 R)-5,28$-stigmastadiene-3 $\beta, 24-$ diol, data from [24]; ${ }^{3} \mathrm{c},(24 S)-5,28-$ stigmastadiene-3 $\beta, 24$-diol, data from [24]; ${ }^{4} \mathrm{~d}$, (24S)-24-ethylcholesta- $3 \beta, 5 \alpha, 6 \beta$-triol, data from [25].

Compound 2 was isolated as a white amorphous solid. The ${ }^{13} \mathrm{C}$ NMR spectrum of compound 2 displayed 29 signals (Table 1), including five quaternary carbons (one ketone carbonyl carbon, one olefinic carbon, and one oxygen-bearing carbon), nine methine carbons (two olefinic carbons and one oxygen-bearing carbon), 10 methylene carbons (one olefinic carbon), and five methyl groups. The molecular formula was established as $\mathrm{C}_{29} \mathrm{H}_{46} \mathrm{O}_{3}$ using HR-EI-MS $\left(\mathrm{m} / z 442.3439\right.$ [M] ${ }^{+}$, calcd. for $\mathrm{C}_{29} \mathrm{H}_{46} \mathrm{O}_{3}$ 442.3447). Comparison of the ${ }^{1} \mathrm{H}$ and ${ }^{13} \mathrm{C}$ NMR data of compound 2 with those of 
compound 1 showed that both compounds shared the same sterol skeleton nucleus and side chain, the only difference being that the signal of $\mathrm{H}-27$ in compound 2 appeared at $\delta_{\mathrm{H}} 0.91(\mathrm{~d}, J=7.2 \mathrm{~Hz})$, whereas the signal of $\mathrm{H}-27$ in compound 1 displayed at $\delta_{\mathrm{H}} 0.89(\mathrm{~d}, J=8.0 \mathrm{~Hz})$. Stereochemistry at C-24 of compound 2 was established to be $S$, since the signal attributed to $\mathrm{H}-27$ at $\delta_{\mathrm{H}} 0.909(3 \mathrm{H}, \mathrm{d}$, $J=7.2 \mathrm{~Hz})$ was very close to that of $\mathrm{H}-21$ at $\delta_{\mathrm{H}} 0.931(3 \mathrm{H}, \mathrm{d}, J=6.8 \mathrm{~Hz})$ in the ${ }^{1} \mathrm{H}$ NMR spectrum of compound 2. The chemical shift difference between H-27 and H-21 of compound 2 was 0.022 ppm, whereas the chemical shift difference between $\mathrm{H}-27$ and $\mathrm{H}-26$ of compound 2 was 0.038 ppm, which was in accordance with those of $24 S$-saringosterol. The chemical shift difference between H-27 and $\mathrm{H}-21$ of $24 S$-saringosterol was 0.019 or $0.020 \mathrm{ppm}$, whereas the chemical shift difference between $\mathrm{H}-27$ and H-26 24S-saringosterol was 0.027 or $0.027 \mathrm{ppm}$ in the previous reports [21,22]. Thus, compound 2 structure was established, and named (24S)-5,28-stigmastadiene-3ß,24-diol-7-one.

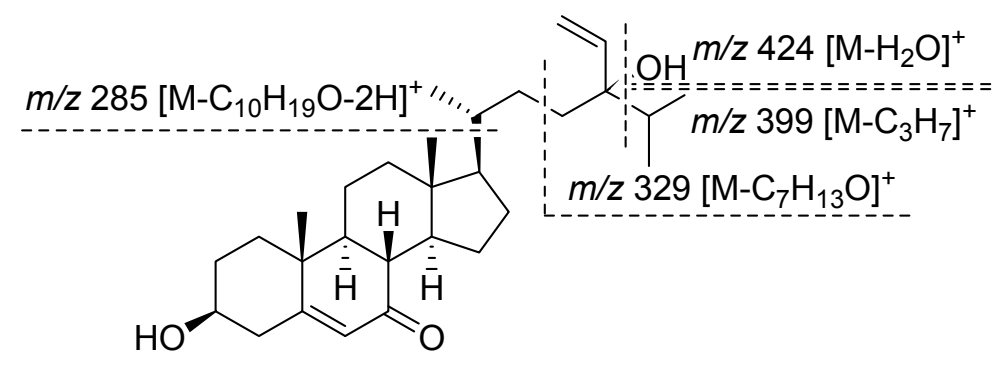

Figure 2. EI-MS fragments of compound 1.

Compound 3 was isolated as a white amorphous solid and its molecular formula was assigned as $\mathrm{C}_{29} \mathrm{H}_{50} \mathrm{O}_{4}$ based on a pseudo-molecular ion peak at $m / z 461.3625[\mathrm{M}-\mathrm{H}]^{-}$(calcd. for $\mathrm{C}_{29} \mathrm{H}_{49} \mathrm{O}_{4}$ 461.3631) in the negative HR-FAB-MS spectrum. The presence of four hydroxyl groups in compound 3 was indicated by the EI-MS spectrum, absence of the molecular ion peak, which exhibited mass ions for stepwise $\mathrm{H}_{2} \mathrm{O}$ loss at $m / z 444\left[\mathrm{M}-\mathrm{H}_{2} \mathrm{O}\right]^{+}, 426\left[\mathrm{M}-2 \mathrm{H}_{2} \mathrm{O}\right]^{+}, 408\left[\mathrm{M}-3 \mathrm{H}_{2} \mathrm{O}\right]^{+}$, and $390\left[\mathrm{M}-4 \mathrm{H}_{2} \mathrm{O}\right]^{+}$. Additional prominent fragment peaks were present at $m / z 401\left[\mathrm{M}-\mathrm{C}_{3} \mathrm{H}_{7}-\mathrm{H}_{2} \mathrm{O}\right]^{+}, 383\left[\mathrm{M}-\mathrm{C}_{3} \mathrm{H}_{7}\right.$ $\left.-2 \mathrm{H}_{2} \mathrm{O}\right]^{+}, 365\left[\mathrm{M}-\mathrm{C}_{3} \mathrm{H}_{7}-3 \mathrm{H}_{2} \mathrm{O}\right]^{+}, 347\left[\mathrm{M}-\mathrm{C}_{3} \mathrm{H}_{7}-4 \mathrm{H}_{2} \mathrm{O}\right]^{+}, 305\left[\mathrm{M}-\mathrm{C}_{10} \mathrm{H}_{19} \mathrm{O}-2 \mathrm{H}\right]^{+}$, $289\left[\mathrm{M}-\mathrm{C}_{10} \mathrm{H}_{19} \mathrm{O}-\mathrm{H}_{2} \mathrm{O}\right]^{+}, 271\left[\mathrm{M}-\mathrm{C}_{10} \mathrm{H}_{19} \mathrm{O}-2 \mathrm{H}_{2} \mathrm{O}\right]^{+}$, and $253\left[\mathrm{M}-\mathrm{C}_{10} \mathrm{H}_{19} \mathrm{O}-3 \mathrm{H}_{2} \mathrm{O}\right]^{+}$ (Figure 3). The ${ }^{13} \mathrm{C}$ NMR spectrum of compound 3 also exhibited 29 signals (Table 1), which included five methyl groups $\left(\delta_{C} 12.1\right.$ (C-18), 16.4 (C-26), 16.8 (C-19), 17.5 (C-27), and $18.7(\mathrm{C}-21)$ ), a sp ${ }^{2}$ methylene carbon $\left(\delta_{C} 112.7 / 112.6(C-29)\right)$, two oxygenated sp ${ }^{3}$ methine carbons $\left(\delta_{C} 67.5(d, C-3)\right.$ and $75.9(d$, C-6)), a sp ${ }^{2}$ methine carbon $\left(\delta_{C} 142.2 / 142.1(\mathrm{C}-28)\right)$, two oxygenated $\mathrm{sp}^{3}$ quaternary carbons $\left(\delta_{\mathrm{C}} 75.9\right.$ (C-5) and 77.5 (C-24)). The ${ }^{1} \mathrm{H}$ NMR spectrum of compound 3 showed tertiary methyl groups at $\delta 0.67$ $(3 \mathrm{H}, \mathrm{s}, \mathrm{H}-18)$ and $1.18(3 \mathrm{H}, \mathrm{s}, \mathrm{H}-19)$, and three secondary methyl groups at $\delta 0.87(3 \mathrm{H}, \mathrm{d}, J=7.2 \mathrm{~Hz}$, $\mathrm{H}-26), 0.90(\mathrm{~d}, J=6.8 \mathrm{~Hz}, \mathrm{H}-27) / 0.89(\mathrm{~d}, J=8.0 \mathrm{~Hz}, \mathrm{H}-27)$, and $0.914(\mathrm{~d}, J=6.4 \mathrm{~Hz}, \mathrm{H}-21) / 0.908$ $(\mathrm{d}, J=7.2 \mathrm{~Hz}, \mathrm{H}-21)$. The $3 \beta, 5 \alpha, 6 \beta$-trihydroxyl sterol nature was characterized by a multiplet at $\delta 4.10(1 \mathrm{H}, \mathrm{H}-3)$, a double doublet at $\delta 2.08(1 \mathrm{H}, J=12.5,12.5 \mathrm{~Hz}, \mathrm{H}-4)$, a multiplet at $\delta 1.60(1 \mathrm{H}$, overlap, H-4), and a broad singlet at $\delta 3.49(1 \mathrm{H}, \mathrm{H}-6)$, while the angular methyl groups at $\mathrm{C}-19$ and $\mathrm{C}-18$ resonated at $\delta 1.18(\mathrm{~s})$ and $0.67(\mathrm{~s})$, respectively [26]. The signal for $\mathrm{H}-6 \alpha$ appeared at $\delta 3.49$ (br s), whereas the signal of $\mathrm{H}-6 \beta$ resonated at about $\delta 3.74(\mathrm{dd}, J=11.5,4.5 \mathrm{~Hz})$; coupling constants of $\mathrm{H}-6 \alpha$ in compound 3 indicated the proton to be equatorial. A singlet for H-19 was observed at $\delta 1.17$ (s), which was shifted downfield with respect to the corresponding signal in the $6 \alpha$-hydroxyl nature that resonated at $\delta 1.05$ (s). The assignments were support by the ${ }^{13} \mathrm{C}$ NMR spectral data of compound 3 and comparison with reference compounds. Up-field shifts were exhibited by C-5 at $\delta 75.9$ and C-7 at $\delta 34.5$, whereas the signal of C-5 and C-7 in $6 \alpha$-hydroxyl nature resonated at about $\delta 77.0$ and 38.1, respectively; downfield shifts were exhibited by $\delta$ C- 6 at 75.9 and C-19 at $\delta 16.8$, whereas the signals of C- 6 and C- 19 in the $6 \alpha$-hydroxyl nature resonated at about $\delta 67.0$ and 15.4 , respectively $[25,27]$. The above data thus demonstrate that compound 3 was a $3 \beta, 5 \alpha, 6 \beta$-trihydroxyl sterol derivative, similar to 
the ring system of (24S)-24-ethylcholesta- $3 \beta, 5 \alpha, 6 \beta$-triol, a known sterol previously isolated from the marine sponge Spirastrella inconstans [25]. The ${ }^{1} \mathrm{H}$ NMR spectrum further exhibited an ABX system at $\delta 5.81(\mathrm{dd}, J=17.2,10.8, \mathrm{H}-28) / 5.79(\mathrm{dd}, J=17.6,10.8, \mathrm{H}-28), 5.19(\mathrm{dd}, J=17.6,1.6 \mathrm{~Hz}, \mathrm{H}-29) / 5.18$ (dd, $J=17.2,2.4 \mathrm{~Hz}, \mathrm{H}-29)$, and $5.14(\mathrm{dd}, J=10.8,2.4 \mathrm{~Hz}, \mathrm{H}-29) / 5.13$ (dd, $J=10.8,1.6 \mathrm{~Hz}, \mathrm{H}-29$ ), due to the presence of a vinyl group attached to a tertiary carbon. These data, in combination with the mass fragments, suggested that compound 3 possessed a 24-hydroxy-24-vinyl side chain and indicated that compound 3 probably consisted of epimers with the ratio of 1:1. In the HMBC spectrum of compound 3, long-range correlations belonging to rings $A$ and $B$ were observed for $\mathrm{H}_{3}-19$ with C-1, C-5, C-9, and C-10, H-4 with C-2, C-3, C-5, C-6, and C-10, H-6 with C-4, C-5, C-9, and C-10, long-range correlations belonging to rings $C$ and $D$ were observed for $\mathrm{H}_{3}-18$ with $C-12, C-13, C-14$, and $\mathrm{C}-17$, long-range corrections belonging to the side chain were observed for $\mathrm{H}_{3}-21$ with $\mathrm{C}-17, \mathrm{C}-20$, and $\mathrm{C}-22, \mathrm{H}_{3}-26$ with $\mathrm{C}-24, \mathrm{C}-25$, and $\mathrm{C}-27, \mathrm{H}_{3}-27$ with $\mathrm{C}-24, \mathrm{C}-25$, and $\mathrm{C}-26, \mathrm{H}-28$ with $\mathrm{C}-24, \mathrm{H}_{2}-29$ with C-24 and C-28. Thus, the structure of compound 3 was determined, and it was named $24 R$ and $24 S$-vinylcholesta-3 $\beta, 5 \alpha, 6 \beta, 24$-tetraol.

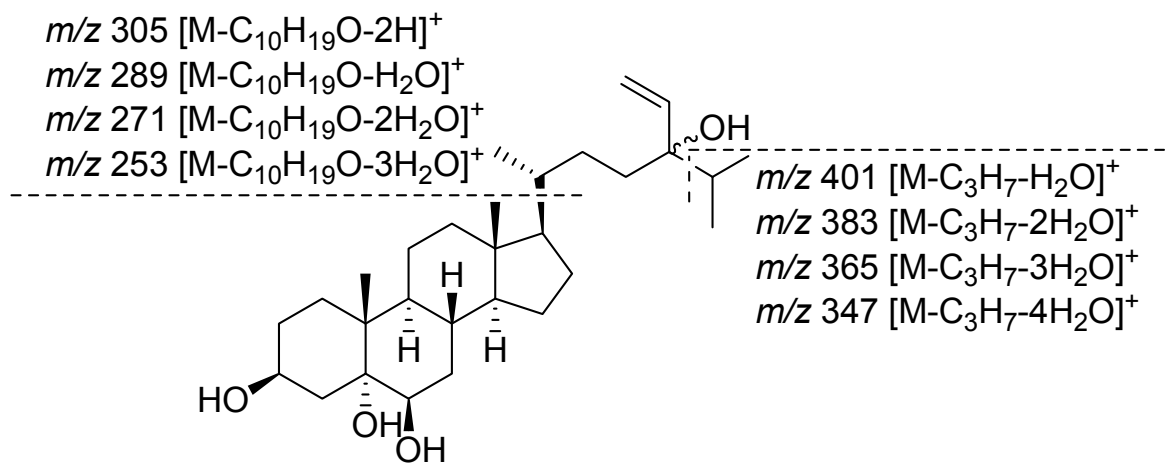

Figure 3. EI-MS fragments of compound 3.

Compounds 4-6 were identified by comparing the ${ }^{1} \mathrm{H}$ - and ${ }^{13} \mathrm{C}-\mathrm{NMR}$, as well as the MS spectra with those reported in the literature. They were identified as isofucoterol (4) [28], 24R,28S and 24S,28R-epoxy-24-ethylcholesterol (5) [29], and (24S)-5,28-stigmastadiene-3ß,24-diol (6) [24].

Aldose reductase, an enzyme of the aldoketo reductase super-family that catalyzes the conversion of glucose to sorbitol in the polyol pathway of glucose metabolism, has been proved as the molecular target for major complications of diabetes, such as cataract, neuropathy, retinopathy, and nephropathy [30]. In this context, aldose reductase inhibitors have received much attention worldwide. In this study, compounds 1-6 and 15 previously isolated compounds were evaluated for human recombinant aldose reductase inhibitory activity. Quercetin, a well-known aldose reductase inhibitor [31-33], was used as a positive control. At the concentration of $3 \mu \mathrm{g} / \mathrm{mL}$ (Table 2), $24 R, 28 \mathrm{~S}$ and 24S,28R-epoxy-24-ethylcholesterol (5), 1-O-palmitoyl-3-O-(6'-sulfo- $\alpha$-D-quinovopyranosyl) glycerol, (2S)-1-O-palmitoyl-3-O-[ $\alpha$-D-galactopyranosyl $(1 \rightarrow 2) \beta$-D-galactopyranosyl] glycerol, 4-hydroxybenzoic acid, 4-hydroxyphenylacetic acid, and 8-hydroxy-(6E)-octenoic acid showed weakly inhibitory activities, with inhibition values of $31.28 \pm 1.04 \%, 27.41 \pm 1.11 \%, 33.89 \pm 1.03 \%$, $27.80 \pm 0.79 \%, 33.05 \pm 1.32 \%$, and $28.92 \pm 0.53 \%$, respectively, which compared with the positive control $(71.66 \pm 0.52 \%)$. In addition, three new sterols $1-3$ were almost inactive. 
Table 2. Human recombinant aldose reductase inhibitory activities of the isolated compounds.

\begin{tabular}{cc}
\hline Compounds & Inhibitory Ratio (\%) \\
\hline 1 & $3.31 \pm 0.85$ \\
2 & $4.08 \pm 0.39$ \\
3 & $2.87 \pm 0.62$ \\
4 & $8.13 \pm 1.76$ \\
5 & $31.28 \pm 1.04$ \\
6 & N.I. ${ }^{1}$ \\
Isophitol & $21.86 \pm 1.21$ \\
Indole-3-carboxylic acid & $10.74 \pm 0.92$ \\
1-O-Palmitoyl-3-O-(6'-sulfo- $\alpha$-D-quinovopyranosyl) glycerol & $27.41 \pm 1.11$ \\
(2S)-1-O-Palmitoyl-3-O-[ $\alpha$-D-galactopyranosyl(1-2) $\beta$-D-galactopyranosyl] glycerol & $33.89 \pm 1.03$ \\
3-Methylsulfoxypropionic acid & $12.42 \pm 0.63$ \\
Tyrosol & $15.81 \pm 1.16$ \\
4-Hydroxybenzoic acid & $27.80 \pm 0.79$ \\
4-Hydroxyphenylacetic acid & $33.05 \pm 1.32$ \\
Loliolide & $8.46 \pm 1.15$ \\
Annuionone D & $18.74 \pm 0.92$ \\
Azelaic acid & $13.38 \pm 0.59$ \\
Succinic acid & $15.98 \pm 0.87$ \\
8-Hydroxy-(6E)-octenoic acid & $28.92 \pm 0.53$ \\
$n$-Butyl $\beta$-D-fructopyranoside & $6.41 \pm 0.88$ \\
$n$-Butyl pyroglutamate & $16.38 \pm 1.87$ \\
Quercetin & $71.66 \pm 0.52$ \\
\hline
\end{tabular}

${ }^{1}$ N.I. $=$ inactive at $3 \mu \mathrm{g} / \mathrm{mL}$.

\section{Materials and Methods}

\subsection{General Experimental Procedures}

EIMS and FABMS were obtained using a JEOL JMS-700 mass spectrometer. NMR spectra were measured on JEOL AL-400 spectrometer (Japan Electronic Optics Laboratory Co. Ltd., Tokyo, Japan). All chemical shifts $(\delta)$ were given in ppm and the samples were solubilized in $\mathrm{CDCl}_{3}$ (Cambridge Isotope Laboratories, Inc., Andover, MA, USA). Optical rotations were measured by using a JASCO P-1020 automatic digital polarimeter (JASCO Corporation, Tokyo, Japan). HPLC was performed on an NPL-500 pump (Nihon Seimitsu Kagaku Co., Ltd., Tokyo, Japan) and a RI-102 detector (Showa Denko Co., Ltd., Tokyo, Japan) using a COSMOSIL Silica 5SL-II Waters column (20 mm $\times 250 \mathrm{~mm}$, Nacalai Tesque, Inc., Kyoto, Japan) and a Senshu Pak DOCOSIL column (10 mm $\times 250 \mathrm{~mm}$, Senshu Scientific Co. Ltd., Tokyo, Japan). Open column chromatography was performed with silica gel $60 \mathrm{~N}$ (100-210 $\mu \mathrm{m}$, Kanto chemical Co., Inc., Tokyo, Japan), RP-18 reverse-phase silica gel (PEGASIL PREP ODS-5015-12A, Senshu Scientific Co. Ltd., Tokyo, Japan), and Sephadex LH-20 (Pharmacia, New Orleans, LA, USA). TLC was carried out on pre-coated TLC plates with silica gel $60 \mathrm{~F}_{254}$ and silica gel RP-18 $60 \mathrm{~F}_{254}(0.25 \mathrm{~mm}$, Merck, Darmstadt, Germany). Detection was achieved by spraying with $10 \% \mathrm{H}_{2} \mathrm{SO}_{4}$ in $\mathrm{MeOH}$ and heating at $110{ }^{\circ} \mathrm{C}$. Aldose reductase recombinant from human muscle cell purchased from Wako Pure Chemical Industries, Ltd. (Osaka, Japan). $\beta$-Nicotinamide adenine dinucleotide phosphate tetrasodium salt (NADPH), DL-glyceraldehyde, sodium dihydrogenphosphate dihydrate, disodium hydrogenphosphate 12-water, and dimethyl sulfoxide (DMSO) were bought from Nacalai Tesque, Inc. (Kyoto, Japan). Compounds isophitol [34], indole-3-carboxylic acid [35], 1-O-palmitoyl-3-O-(6'-sulfo- $\alpha$-D-quinovopyranosyl) glycerol [36], (2S)-1-O-palmitoyl-3-O-[ $\alpha$-D-galactopyranosyl(1 $\rightarrow 2) \beta$-D-galactopyranosyl] glycerol [37], 3-methylsulfoxypropionic acid [38], tyrosol [39], 4-hydroxybenzoic acid [40], loliolide [41], annuionone D [42], azelaic acid [43], succinic acid [44], 8-hydroxy-(6E)-octenoic acid [45], $n$-butyl $\beta$-D-fructopyranoside [46], and $n$-butyl pyroglutamate [47] were isolated and identified from this alga in our laboratory. 


\subsection{Algal Material}

The wild green alga Ulva australis was collected at the coast of Dalian, China, in October 2002 and identified by Professor Zi'ang Yao (School of Life Science and Technology, Dalian University, Dalian, China). A voucher specimen (20021001) was deposited at the Department of Natural Medicine and Pharmacognosy, School of Pharmacy, Qingdao University, Qingdao, China.

\subsection{Extraction and Isolation}

Air-dried $U$. australis $(27 \mathrm{~kg}$ ) was powered and reflux extracted twice with 95\% EtOH for $4 \mathrm{~h}$. Evaporation of the solvent under reduced pressure gave the EtOH extract $(1.8 \mathrm{~kg})$. The EtOH extract $(1.2 \mathrm{~kg})$ was suspended in water and successively partitioned with hexane, EtOAc, and $n-\mathrm{BuOH}$ to give the hexane soluble part (137.9 g), EtOAc soluble part (25.7 g), and $n$ - $\mathrm{BuOH}$ soluble part (20.2 g), respectively. The hexane soluble part was chromatographed on a silica gel column eluting with a gradient of hexane-EtOAc (20:1, 10:1, 5:1; 1:1, 1:3, v/v), EtOAc, a gradient of EtOAc-MeOH (5:1, $1: 1, v / v$ ), and $\mathrm{MeOH}$ to give 24 fractions (Fr. 1-Fr. 24) on the basic of TLC analyses. Fr. 10 was purified by normal-phase preparative HPLC using hexane:EtOAc $(3: 1, v / v)$ as the mobile phase and reversed-phase preparative HPLC using $\mathrm{MeOH}$ as the mobile phase at a flow rate of $2.0 \mathrm{~mL} / \mathrm{min}$ resulting in the isolation of compounds $4(132 \mathrm{mg}), \mathbf{5}(40.2 \mathrm{mg})$, and $\mathbf{6}(3.0 \mathrm{mg})$. Fr. 13 was subjected to column chromatography on Sephadex LH-20 using $\mathrm{MeOH}$ as an eluent, yielding sub-fractions (Fr. 13-1-Fr. 13-3). Fr. 13-2 was further separated by RP-18 silica gel column chromatography eluting with $\mathrm{MeOH}$ to finish sub-fractions, which were purified by reversed-phase preparative HPLC employing $\mathrm{MeOH}: \mathrm{H}_{2} \mathrm{O}(85: 15, v / v)$ as the mobile phase at a flow rate of $2.0 \mathrm{~mL} / \mathrm{min}$ to give compound $\mathbf{1}(4.3 \mathrm{mg})$. Fr. 14 was isolated by Sephadex LH-20 column chromatography eluting with $\mathrm{MeOH}, \mathrm{RP}-18$ silica gel column chromatography eluting with $\mathrm{MeOH}: \mathrm{H}_{2} \mathrm{O}(80: 20, v / v)$, reverse-phase preparative HPLC eluting with $\mathrm{MeOH}: \mathrm{H}_{2} \mathrm{O}(85: 15, v / v)$ at a flow rate of $2.0 \mathrm{~mL} / \mathrm{min}$, and normal-phase preparative HPLC eluting with hexane: EtOAc $(2: 3, v / v)$ at a flow rate of $2.0 \mathrm{~mL} / \mathrm{min}$ to yield compound $2(5.5 \mathrm{mg})$. Fr. 16 was chromatographed on a RP-18 silica gel column and eluted using $\mathrm{MeOH}$, and reverse-phase preparative HPLC $\left(\mathrm{MeOH}-\mathrm{H}_{2} \mathrm{O}, 85: 15, v / v, 2.0 \mathrm{~mL} / \mathrm{min}\right)$ to obtain compound $3(2.4 \mathrm{mg})$.

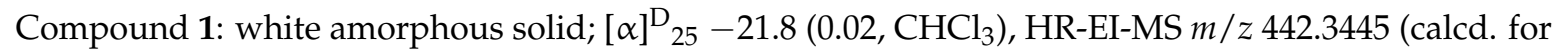
$\mathrm{C}_{29} \mathrm{H}_{48} \mathrm{O}_{3}, 442.3447$ ); EI-MS m/z 442 [M] ${ }^{+}$(32), 424 (11), 399 (92), 381 (100), 344 (70), 329 (21), 285 (92); ${ }^{1} \mathrm{H} \mathrm{NMR}\left(\mathrm{CDCl}_{3}, 400 \mathrm{MHz}\right) \delta 5.81(1 \mathrm{H}, \mathrm{dd}, J=17.6,10.8, \mathrm{H}-28), 5.69(1 \mathrm{H}, \mathrm{d}, J=1.6 \mathrm{~Hz}, \mathrm{H}-6), 5.20(1 \mathrm{H}$, dd, $J=17.6,1.6 \mathrm{~Hz}, \mathrm{H}-29), 5.14(1 \mathrm{H}, \mathrm{dd}, J=10.8,1.6 \mathrm{~Hz}, \mathrm{H}-29), 3.67(1 \mathrm{H}, \mathrm{m}, \mathrm{H}-3), 1.20$ (3H, s, H-19), $0.931(\mathrm{~d}, J=6.4 \mathrm{~Hz}, \mathrm{H}-21), 0.890(3 \mathrm{H}, \mathrm{d}, J=8.0 \mathrm{~Hz}, \mathrm{H}-27), 0.871(3 \mathrm{H}, \mathrm{d}, J=7.2 \mathrm{~Hz}, \mathrm{H}-26), 0.68(3 \mathrm{H}, \mathrm{s}$, $\mathrm{H}-18) ;{ }^{13} \mathrm{C} \mathrm{NMR}\left(\mathrm{CDCl}_{3}, 100 \mathrm{MHz}\right)$ spectra data, see Table 1.

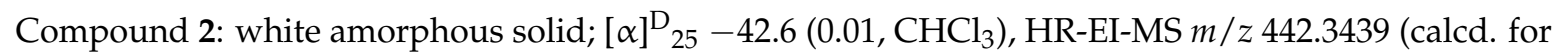
$\mathrm{C}_{29} \mathrm{H}_{46} \mathrm{O}_{3}$ 442.3447); EI-MS m/z 442 [M] (35), 424 (16), 399 (20), 381 (25), 344 (18), 329 (9), 285 (100); ${ }^{1} \mathrm{H}$ NMR $\left(\mathrm{CDCl}_{3}, 400 \mathrm{MHz}\right) \delta 5.81(1 \mathrm{H}, \mathrm{dd}, J=17.6,10.8, \mathrm{H}-28), 5.69(1 \mathrm{H}, \mathrm{d}, J=1.6 \mathrm{~Hz}, \mathrm{H}-6), 5.19(1 \mathrm{H}$, $\mathrm{dd}, J=17.6,1.6 \mathrm{~Hz}, \mathrm{H}-29), 5.14(1 \mathrm{H}, \mathrm{dd}, J=10.8,1.6 \mathrm{~Hz}, \mathrm{H}-29), 3.67$ (1H, m, H-3), 1.20 (3H, s, H-19), $0.931(\mathrm{~d}, J=6.8 \mathrm{~Hz}, \mathrm{H}-21), 0.909(3 \mathrm{H}, \mathrm{d}, J=7.2 \mathrm{~Hz}, \mathrm{H}-27), 0.871(3 \mathrm{H}, \mathrm{d}, J=7.2 \mathrm{~Hz}, \mathrm{H}-26), 0.68(3 \mathrm{H}, \mathrm{s}$, $\mathrm{H}-18) ;{ }^{13} \mathrm{C}$ NMR $\left(\mathrm{CDCl}_{3}, 100 \mathrm{MHz}\right)$ spectra data, see Table 1.

Compound 3 (a mixture of $24 R$ and 24S): white amorphous solid; negative HR-FAB-MS $m / z 461.3625$ (calcd. for $\mathrm{C}_{29} \mathrm{H}_{49} \mathrm{O}_{4} 461.3631$ ); EI-MS m/z 444 (11), 426 (26), 408 (8), 401 (73), 390 (2), 383 (100), 365 (68), 347 (23), 305 (83), 289 (52), 271 (70), 253 (27); ${ }^{1} \mathrm{H} \mathrm{NMR}\left(\mathrm{CDCl}_{3}, 400 \mathrm{MHz}\right) \delta 5.81$ (dd, J = 17.2, 10.8, H-28)/5.79 (dd, $J=17.6,10.8, \mathrm{H}-28), 5.19$ (dd, $J=17.6,1.6 \mathrm{~Hz}, \mathrm{H}-29) / 5.18(\mathrm{dd}, J=17.2,2.4 \mathrm{~Hz}$, H-29), $5.14(\mathrm{dd}, J=10.8,2.4 \mathrm{~Hz}, \mathrm{H}-29) / 5.13(\mathrm{dd}, J=10.8,1.6 \mathrm{~Hz}, \mathrm{H}-29), 4.10(1 \mathrm{H}, \mathrm{m}, \mathrm{H}-3), 3.49(1 \mathrm{H}, \mathrm{br} \mathrm{s}$, $\mathrm{H}-6), 2.08(1 \mathrm{H}, J=12.5,12.5 \mathrm{~Hz}, \mathrm{H}-4), 1.60(1 \mathrm{H}$, overlap, H-4), $1.18(3 \mathrm{H}, \mathrm{s}, \mathrm{H}-19), 0.914$ (d, J = $6.4 \mathrm{~Hz}$, $\mathrm{H}-21) / 0.908(\mathrm{~d}, J=7.2 \mathrm{~Hz}, \mathrm{H}-21), 0.90(\mathrm{~d}, J=6.8, \mathrm{H}-27) / 0.89(\mathrm{~d}, J=8.0 \mathrm{~Hz}), 0.87(3 \mathrm{H}, \mathrm{d}, J=7.2 \mathrm{~Hz}$, $\mathrm{H}-26), 0.67$ (3H, s, H-18); ${ }^{13} \mathrm{C}$ NMR $\left(\mathrm{CDCl}_{3}, 100 \mathrm{MHz}\right)$ spectra data, see Table 1. 


\subsection{Human Recombinant Aldose Reductase Inhibitory Activity Assay}

The human recombinant aldose reductase inhibition assays were performed according to the method modified by our group [19]. The assay was performed at $25{ }^{\circ} \mathrm{C}$ in a $200 \mathrm{mM}$ sodium phosphate buffer solution ( $\mathrm{pH}$ 6.2) $(700 \mu \mathrm{L})$, containing $1.5 \mathrm{mM}$ NADPH solution $(100 \mu \mathrm{L}), 100 \mathrm{mM}$ DL-glyceraldehyde solution $(100 \mu \mathrm{L})$, and $3 \times 10^{-2}$ unit $/ \mathrm{mL}$ human recombinant aldose reductase solution $(100 \mu \mathrm{L})$, in the total volume of $1.0 \mathrm{~mL}$. The effects of each sample on the enzyme activity were determined by adding $3 \mu \mathrm{L}$ of test sample solution (final concentration $3 \mu \mathrm{g} / \mathrm{mL}$ dissolved in $100 \%$ DMSO) to the reaction mixture. An appropriate blank control mixture and positive control mixture were prepared. The reaction was initiated by the addition of DL-glyceraldehyde solution and the rate of NADPH oxidation was followed by recording the decrease in the absorbance at $340 \mathrm{~nm}$ on a UV spectrophotometer (SHIMADZU UV 1600, Kyoto, Japan). Inhibition percentage (\%) was calculated as $\left[1-\left(\Delta \mathrm{A}_{\mathrm{s}}-\Delta \mathrm{A}_{\mathrm{b}}\right) /\left(\Delta \mathrm{A}_{\mathrm{c}}-\Delta \mathrm{A}_{\mathrm{b}}\right)\right] \times 100$, where $\mathrm{A}_{\mathrm{s}}$ is the decreased absorbance of the sample, $\mathrm{A}_{\mathrm{c}}$ and $\mathrm{A}_{\mathrm{b}}$ are the decreased absorbances without a sample as a positive control and without a sample and enzyme as a blank control, respectively. An overview about the effects of these substances on human recombinant aldose reductase inhibitory activity is given in Table 2.

\section{Conclusions}

Phytochemistry investigation of the green alga $U$. australis led to the isolation of three new sterols and three known sterols. These compounds, together with the previously isolated secondary metabolites of this alga, were investigated for their inhibitory effects on aldose reductase in vitro. Of the compounds, $24 R, 28 S$ and $24 S, 28 R$-epoxy-24-ethylcholesterol (5), 1-O-palmitoyl-3-O-(6'-sulfo- $\alpha$-D-quinovopyranosyl) glycerol, (2S)-1-O-palmitoyl-3-O-[ $\alpha$-Dgalactopyranosyl $(1 \rightarrow 2) \beta$-D-galactopyranosyl] glycerol, 4-hydroxybenzoic acid, 4-hydroxyphenylacetic acid, and 8-hydroxy-(6E)-octenoic acid weakly inhibited the enzyme. The obtained results are beneficial to subsequent research on this alga.

Acknowledgments: This project was supported by the National Natural Science Foundation of China under Grant 30672599.

Author Contributions: The contributions of the respective authors are as follows: G.-L.L., R.-R.W., and Y.-X.H. performed the extraction, isolation, and elucidation of the constituents. W.-J.G. and G.-B.W. were involved in the biological evaluations. K.L. and Y.L. contributed to checking and confirming all of the procedures of the isolation and identification. W.W. designed the study, supervised the laboratory work, and contributed to the critical reading of the manuscript. All the authors have read the final manuscript and approved the submission.

Conflicts of Interest: The authors declare no conflict of interest.

\section{References}

1. Blunt, J.W.; Copp, B.R.; Keyzers, R.A.; Munro, M.H.G.; Prinsep, M.R. Marine natural products. Nat. Prod. Rep. 2015, 32, 116-211. [CrossRef] [PubMed]

2. Blunt, J.W.; Copp, B.R.; Keyzers, R.A.; Munro, M.H.G.; Prinsep, M.R. Marine natural products. Nat. Prod. Rep. 2016, 33, 382-431. [CrossRef] [PubMed]

3. Blunt, J.W.; Copp, B.R.; Keyzers, R.A.; Munro, M.H.G.; Prinsep, M.R. Marine natural products. Nat. Prod. Rep. 2017, 34, 235-294. [CrossRef] [PubMed]

4. Sakai, R.; Swanson, G.T. Recent progress in neuroactive marine natural products. Nat. Prod. Rep. 2014, 31 , 273-309. [CrossRef] [PubMed]

5. Sunassee, S.N.; Davies-Coleman, M.T. Cytotoxic and antioxidant marine prenylated quinones and hydroquinones. Nat. Prod. Rep. 2012, 29, 513-535. [CrossRef] [PubMed]

6. Lahaye, M.; Jegou, D. Chemical and physical-chemical characteristics of dietary fibers from Ulva lactuca (L.) Thuret and Enteromorpha compressa (L.) Grev. J. Appl. Phycol. 1993, 5, 195-200. [CrossRef] 
7. Ali, I.; Manzoor, Z.; Koo, J.E.; Kim, J.E.; Byeon, S.H.; Yoo, E.S.; Kang, H.K.; Hyun, J.W.; Lee, N.H.; Koh, Y.S. 3-Hydroxy-4,7-megastigmadien-9-one, isolated from Ulva pertusa, attenuates TLR9-mediated inflammatory response by down-regulating mitogen-activated protein kinase and NF-кB pathways. Pharm. Biol. 2016, 55, 435-440. [CrossRef] [PubMed]

8. Yu, P.Z.; Li, N.; Liu, X.G.; Zhou, G.F.; Zhang, Q.B.; Li, P.C. Antihyperlipidemic effects of different molecular weight sulfated polysaccharides from Ulva pertusa (Chlorophyta). Pharmacol. Res. 2003, 48, 543-549.

9. Zeng, C.; Tseng, C.K.; Zhang, J.; Chang, C.F. Chinese seaweeds in herbal medicine. Hydrobiology 1984, 116-117, 152-155.

10. Qi, H.M.; Huang, L.Y.; Liu, X.L.; Liu, D.M.; Zhang, Q.B.; Liu, S.M. Antihyperlipidemic activity of high sulfate content derivative of polysaccharide extracted from Ulva pertusa (Chlorophyta). Carbohydr. Polym. 2012, 87, 1637-1640. [CrossRef]

11. Qi, H.M.; Zhang, Q.B.; Zhao, T.T.; Chen, R.; Zhang, H.; Niu, X.Z.; Li, Z.E. Antioxidant activity of different sulfate content derivatives of polysaccharide extracted from Ulva pertusa (Chlorophyta) in vitro. Int. J. Biol. Macromol. 2005, 37, 195-199. [CrossRef] [PubMed]

12. Song, L.; Chen, X.L.; Liu, X.D.; Zhang, F.B.; Hu, L.F.; Yue, Y.; Li, K.C.; Li, P.C. Characterization and comparison of the structural features, immune-modulatory and anti-avian influenza virus activities conferred by three algal sulfated polysaccharides. Mar. Drugs 2016, 14, 4. [CrossRef] [PubMed]

13. Bian, J.; Chu, Z.Y.; Bao, L.L.; Cheng, X.; Liang, X.F.; Liu, X.J.; Zhou, X. Effect of polysaccharide from Ulva pertusa on immune function in mice. Chin. J. Biochem. Pharm. 2006, 27, 276-279.

14. Shi, J.M.; Cheng, C.L.; Zhao, H.T.; Jing, J.; Gong, N.; Lu, W.H. In vivo anti-radiation activities of the Ulva pertusa polysaccharides and polysaccharide-iron (III) complex. Int. J. Biol. Macromol. 2013, 60, 341-346. [CrossRef] [PubMed]

15. Xu, J.H.; Lu, Q.H.; Zhao, Y. Studies on the chemical constituents of green algae Ulva pertusa. China J. Chin. Mater. Med. 2007, 32, 1536-1538.

16. Lu, Q.H.; Xu, J.H.; Zhao, Y.; Zhou, C.X. Studies on chemical constituents of Ulva pertusa. Chin. Pharm. J. 2008, $43,582-584$.

17. Wang, C.Y.; Han, L.; Kang, K.; Shao, C.L.; Wei, Y.X.; Zheng, C.J.; Guan, H.S. Secondary metabolites from green algae Ulva pertusa. Chem. Nat. Comp. 2010, 46, 828-830. [CrossRef]

18. Ali, I.; Manzoor, Z.; Koh, Y.S. 3-Hydroxy-4,7-megastigmadien-9-one, isolated from Ulva pertusa, inhibits LPS-induces inflammatory response by down-regulating mitogen-activated protein kinase and NF- $\mathrm{KB}$ pathways. J. Bacteriol. Virol. 2016, 46, 167-172. [CrossRef]

19. Wang, W.; Okada, Y.; Shi, H.B.; Wang, Y.Q.; Okuyama, T. Structures and aldose reductase inhibitory effects of bromophenols from the red alga Symphyocladia latiuscula. J. Nat. Prod. 2005, 68, 620-622. [CrossRef] [PubMed]

20. Islam, M.N.; Choi, S.H.; Moon, H.E.; Park, J.J.; Jung, H.A.; Woo, M.H.; Woo, H.C.; Choi, J.S. The inhibitory activities of the edible green alga Capsosiphon fulvescens on rat lens aldose reductase and advanced glycation end products formation. Eur. J. Nutr. 2014, 55, 233-242. [CrossRef] [PubMed]

21. Catalan, C.A.; Kokke, W.C.M.C.; Duque, C.; Djerassi, C. Synthesis of (24R)- and (24S)-5,28-stigmastadien$3 \beta$-ol and determination of the stereochemistry of their 24-hydroxy analogues, the saringosterols. J. Org. Chem. 1983, 48, 5207-5214. [CrossRef]

22. Chen, Z.; Liu, J.; Fu, Z.F.; Ye, C.; Zhang, R.S.; Song, Y.Y.; Zhang, Y.; Li, H.H.; Ying, H.; Liu, H.B. 24(S)-Saringosterol from edible marine seaweed Sargassum fusiforme is a novel selective LXR $\beta$ agonist. J. Agric. Food Chem. 2014, 62, 6130-6137. [CrossRef] [PubMed]

23. Ahmad, V.U.; Aliya, R.; Perveen, S.; Shameel, M. Sterols from marine alga Codium decorticatum. Phytochemistry 1993, 33, 1189-1192. [CrossRef]

24. Wang, W.; Li, H.Y.; Wang, Y.Y.; Xia, X.; Okada, Y.; Okuyama, T. Chemical constituents from brown alga Sargassum fusiforme. Chin. Tradit. Herb. Drugs 2008, 39, 657-661.

25. Das, B.; Srinivas, K.V.N.S. Studies on marine chemicals, part IV. Isolation of cholesterol derivatives from the marine sponge Spirastrella inconstans. J. Nat. Prod. 1992, 55, 1310-1312. [CrossRef]

26. Notano, G.; Piccialli, V.; Sica, D. $3 \beta, 5 \alpha, 6 \beta$-Trihydroxylated sterols with a saturated nucleus from two populations of the marine sponge Cliona copiosa. J. Nat. Prod. 1991, 54, 1570-1575. [CrossRef]

27. Das, B.; Rao, S.P.; Srinivas, K.V.N.S. Studies on marine chemicals, part VI. A new clionasterol derivative from the marine sponge Spirastrella inconstans. J. Nat. Prod. 1992, 56, 2210-2211. [CrossRef] 
28. Nicotra, F.; Toma, L. A convenient procedure for the conversion of fucosterol into isofucosterol. Gazz. Chim. Itali. 1980, 110, 579-580.

29. Tang, H.F.; Yi, Y.H.; Yao, X.S.; Zhou, D.Z.; Lv, T.S.; Jiang, Y.P. Studies on the bioactive steriod constituents from Sargassum carpophyllum. Chin. Pharm. J. 2002, 37, 262-265.

30. Grewal, A.S.; Bhardwaj, S.; Pandita, D.; Lather, V.; Sekhon, B.S. Updates on aldose reductase inhibitors for management of diabetic complications and non-diabetic diseases. Mini-Rev. Med. Chem. 2016, 16, 120-162. [CrossRef] [PubMed]

31. Lee, J.; Ryu, H.S.; Rodriguez, J.P.; Lee, S. Aldose reductase inhibitory activity of quercetin from the stem of Rhododendron mucronulatum for. albiflorum. J. Appl. Biol. Chem. 2017, 60, 29-33. [CrossRef]

32. Kim, S.B.; Hwang, S.H.; Suh, H.W.; Lim, S.S. Phytochemical analysis of Agrimonia pilosa Ledeb, its antioxidant activity and aldose reductase inhibitory potential. Int. J. Mol. Sci. 2017, 18, 379. [CrossRef] [PubMed]

33. Du, L.; Hao, M.; Li, C.C.; Wu, W.Y.; Wang, W.W.; Ma, Z.X.; Yang, T.T.; Zhang, N.; Isaac, A.T.; Zhu, X.; et al. Quercetin inhibited epithelial mesenchymal transition in diabetic rats, high-glucose-cultured lens, and SRA01/04 cells through transforming growth factor- $\beta 2 /$ phosphoinositide 3-kinase/Akt pathway. Mol. Cell. Endocrinol. 2017, 452, 44-56. [CrossRef] [PubMed]

34. Ahmad, V.U.; Ali, M.S. Terpenoids from marine red alga Laurencia pinnatifida. Phytochemistry 1991, 30, 4172-4174. [CrossRef]

35. Huang, Y.; Wu, X.; Wen, J.W.; Chen, M.S.; He, K.J.; Liu, B.M. Chemical constituents of Pilea sinofasciata. Chin. Tradit. Herb. Drugs 2016, 47, 3159-3163.

36. Sakamoto, B.; Hokama, Y.; Horgen, F.D.; Scheuer, P.J.; Kan, Y.; Nagai, H. Isolation of a sulfoquinovosyl monoacylglycerol from Bryopsis sp. (Chlorophyta): Identification of a factor causing a possible species-specific ecdysis response in Gambierdiscus toxicus (Dinophyceae). J. Phycol. 2000, 36, 924-931. [CrossRef]

37. Murakami, N.; Morimito, T.; Imamura, H.; Nagatsu, A.; Sakakibara, J. Enzymatic transformation of glyceroglycolipids into sn-1 and sn-2 lysoglyceroglycolipids by use of Rhizopus arrhizus lipase. Tetrahedron 1994, 50, 1993-2002. [CrossRef]

38. Doi, J.T.; Goodrow, M.H.; Musker, W.K. Neighboring group participation in organic redox reactions. 11. Anchimeric assistance by the carboxylate anion in aqueous iodine oxidations of 3-(alkylthio)propanoates. J. Org. Chem. 1986, 51, 1026-1029. [CrossRef]

39. Wang, X.F.; Li, C.; Zheng, Y.Y.; Di, D.L. Polyphenols from leaves of Olea europaea. Chin. Tradit. Herb. Drugs 2011, 42, 848-851.

40. Wang, X.J.; Xie, X.; Luo, X.; Song, Y.L.; Zhao, Y.W.; Huang, W.Z.; Wang, Z.Z.; Xiao, W. Chemical constituents from Rhodiola wallichiana var. cholaensis (I). Chin. Tradit. Herb. Drugs 2015, 46, 3471-3474.

41. Kimura, J.; Maki, N. New loliolide derivative from the brown alga Undaria ponnatifida. J. Nat. Prod. 2002, 65, 57-58. [CrossRef] [PubMed]

42. Fu, L.R.; Ma, Q.Y.; Huang, S.Z.; Yu, Z.F.; Zhao, Y.X. Chemical constituents from stems of Cipadessa cinerascens. Chin. Tradit. Herb. Drugs 2015, 46, 633-638.

43. Wang, Q.; Xu, Y.Y. Chemical constituents of Aganosma marginata. Chin. Tradit. Herb. Drugs 2015, 46, $1742-1748$.

44. Lin, J.B.; Zhao, L.C.; Guo, J.Z.; Liu, L.; Kuang, Y.; Yang, S.X. Chemical constituents from aerial parts of Fagopyrum dibotrys. Chin. Tradit. Herb. Drugs 2016, 47, 1841-1844.

45. Suzuki, Y.; Seki, T.; Tanaka, S.; Kitamura, M. Intramolecular tsuji-trost-type allylation of carboxylic acids: Asymmetric synthesis of highly $\pi$-allyl donative lactones. J. Am. Chem. Soc. 2015, 137, 9539-9542. [CrossRef] [PubMed]

46. Zhang, C.Z.; Xu, X.Z.; Li, C. Fructosides from Cynomorium songaricum. Phytochemistry 1996, 41, $975-976$. [CrossRef]

47. Tang, Y.P.; Yu, B.; Hu, J.; Wu, T.; Hui, Y.Z. The chemical constituents from the bulbs of Ornithogalum caudatum. J. Chin. Pharm. Sci. 2001, 10, 169-171.

(C) 2017 by the authors. Licensee MDPI, Basel, Switzerland. This article is an open access article distributed under the terms and conditions of the Creative Commons Attribution (CC BY) license (http:/ / creativecommons.org/licenses/by/4.0/). 